\title{
Interrogações a um campo teórico em crise.
}

\author{
CIBELE SALIBA RIZEK
}

RESUMO: Este artigo tem por base a discussão de alguns conceitos desenvolvidos pela Sociologia do Trabalho e pela Teoria do Processo de Trabalho. Entre eles podem ser destacados a questão da perda da centralidade do trabalho nas sociedades contemporâneas, as dimensões da subjetividade dos trabalhadores e as idéias de controle e consentimento. As indagações presentes no texto foram formuladas durante pesquisa, cuja investigação estava centrada nos trabalhadores da primeira central de matérias-primas de produtos petroquímicos do Brasil, buscando explicar as metáforas que foram construídas para descrever seu trabalho, a empresa e a si mesmos. Suas práticas e imagens poderiam ser consideradas como o resultado de uma gestão empresarial assentada sobre o consenso e, por isso, completamente bem sucedida. A recusa dessa interpretação acabou por gerar outra maneira de explicação e análise dos dados, processo que acabou por desencadear as interrogações presentes neste texto.

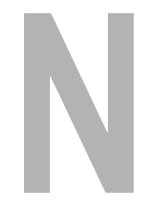

ossas interrogações ${ }^{1}$ voltam-se para algumas das discussões já clássicas da sociologia do trabalho: a primeira diz respeito ao debate recente sobre o esgotamento da centralidade da categoria trabalho, naquilo que Offe chama de sua "forma pura"; a segunda é nucleada pelo debate anglo-saxão em particular, especialmente nas dimensões do controle e nas formas de consentimento geradas no interior das empresas. Essa questão tem desdobramentos importantes no que se refere a um tema que adquiriu força nos anos oitenta, dentro do campo da teoria do processo de trabalho: a noção de subjetividade, com ênfases diversas na sociologia de influência anglo-saxônica e na reflexão brasileira. Interrogar alguns desses eixos temáticos a partir dos achados de pesquisa é inserí-la no campo de investigação ao qual
UNITERIMOS:

processo de trabalho, subjetividade e trabalho, controle gerencial.
Professora do Depto. de Arquitetura e Planejamento da FESC-USP 
ela se filia, estabelecendo as interlocuções que lhe são inerentes.

\section{Trabalho e Modernidade}

Como se sabe, a noção de trabalho constitui uma das mais importantes idéias construtoras da modernidade. É mesmo possível pensar que as dimensões vinculadas às novas realidades que tomaram forma nos fins do século XVIII e início do século XIX tenham se tornado a pedra angular de uma nova imagem e de um novo imaginário a respeito das relações sociais, sem os quais o que chamamos hoje de a sociedade mal poderia ser definido. As transformações do trabalho e da produção, bem como um novo conceito de trabalho e de razão, foram axiais para que uma ciência da sociedade pudesse se instituir como um pensamento que fala de um outro tornado objeto, passível de descodificação apenas por um novo olhar que, nesse mesmo processo, se constitui como sujeito de um conhecimento não mais sobre uma experiência compartilhada por um nós, mas sobre eles, os outros: os pobres, os miseráveis, os doentes, os trabalhadores.

Quando se toma como eixo a própria noção de trabalho em suas diversas expressões, uma primeira questão se coloca: trata-se fundamentalmente de pensar a noção de natureza. É pelo contraponto homem/natureza, perseguido por toda tradição filosófica ocidental, que as dimensões do trabalho e da produção humanas foram (e ainda são) problematizadas. De muitas maneiras, contrapostas ou não, ao discutir a noção de trabalho, o que se discute é a especificidade humana frente às dimensões da natureza. Ora, é exatamente quando esta especificidade se assoberba a ponto de criar um ambiente que se transforma, para onde quer que se olhe, em uma natureza produzida e artificial - uma produção humana que adquire a amplitude e o caráter de uma segunda natureza -, que as dimensões do trabalho são revisitadas por uma nova sensibilidade cientificizada.

Ao se olhar com atenção para o nascimento da noção de sociedade como objeto, para sua construção, as dimensões do trabalho, quer como princípio organizativo ou como pressuposto lógico, estão claramente colocadas e articuladas. Antes mesmo do nascimento das ciências da sociedade, na tessitura das relações que construiriam a modernidade, o estatuto lógico do trabalho humano tinha se transformado. São bastante conhecidas as formas pré-modernas de concepção da atividade humana. Tanto para o mundo clássico como para o mundo medieval, a vida contemplativa é o fundamento da esfera propriamente humana investida de nobreza e dignidade. Cabe sobretudo lembrar, como faz H. Arendt, retomando o mundo e o pensamento da antiguidade clássica, uma diferença que não aparece nos paradigmas fundadores da sociologia: a diferença entre labor e trabalho. Nesta distinção, são formas diferentes de relação com a natureza que são problematizadas: "o labor do nosso corpo e o trabalho de nossas mãos" (Locke, 1983, p. 90). O labor, instância metabólica e vital, nos inscreve no 
RIZEK, Cibele Saliba. Interrogações a um campo teórico em crise. Tempo Social; Rev. Sociol. USP, S. Paulo, 6(1-2): 147-179, 1994 (editado em jun. 1995).

mundo natural, é natureza, corpo. O trabalho tem como condição a produção de um mundo artificial de coisas; corresponde, portanto, ao artificialismo da existência humana. Entretanto, nem trabalho nem labor podiam sustentar, até a inauguração da modernidade, um bios, isto é, um modo de vida autônomo e autenticamente humano, já que pertenciam, ambos, ao reino da necessidade e, por isso, contrapunham-se ao reino da liberdade, identificado com a esfera pública da ação e da palavra. Essa transformação é crucial: de condição privada assimilada ao reino da necessidade, as dimensões do trabalho passam a conformar o reino da liberdade. Aquilo que impedia a autonomia dos homens passa a ser sua condição de liberdade e de dignidade.

Assim, se o trabalho muda de significação ao longo do processo de construção daquilo que alguns teóricos chamam de "sociedade do trabalho", também a idéia de natureza se transforma: não se trata mais de uma natureza transcendente, sagrada, mágica. Pari passu com a construção do mundo moderno, a natureza se laiciza, torna-se um objeto de explicação racional, aparece cada vez mais como dimensão quantificável e abstrata, regida por leis universais e eternas. Da natureza mágica e divinizada à natureza abstrata e quantificável, assim também pode-se pensar uma natureza humana laicizada, igualmente abstrata e quantificável. Dois dos três grandes paradigmas clássicos da sociologia apontam com nomes e formas diferentes a maneira como essa transformação se dá, promovendo a passagem dos modos de vida "tradicionais" para um modo de vida "racional e burocrático", ou pensado como um modo capitalista de produção. Como quer que se identifique a modernidade, como racionalização da vida, como modo capitalista de produção ou como forma social complexa e organicamente estruturada, é imprescindível observar que o nascimento das ciências sociais faz parte do registro a partir do qual a própria modernidade adquire autoconsciência, concebe a si mesma como fundadora de um novo tempo, como uma nova consciência do tempo (cf. Habermas, 1987).

Vinculando o nascimento da sociologia ao nascimento avassalador do trabalho como forma pura, isto é, livre da mistura de outras esferas de ação humana e social, bem como de outras funções socialmente significativas, Offe argumenta que é isso que torna possível o vínculo entre uma noção abstrata de trabalho e a figura do trabalhador. Esse trabalho livre, que começa a surgir como condição "naturalmente" associada à condição dos trabalhadores, constituiu-se, como se pode facilmente constatar, como ponto de partida das construções sociológicas clássicas. Diante da indagação não-conclusiva de que teria havido uma implosão da categoria trabalho pela perda de sua importância relativa como elemento estruturador das sociedades, este autor tenta mapear os indícios de uma resposta positiva.

A diferenciação interna do conjunto de atividades que se abrigam na esfera do que se poderia hoje denominar de trabalho não mais permite 
localizar interesses e formas de ação a partir da inserção na estrutura produtiva. Assim, também não seria mais possível detectar esse espectro de nuances e diferenças pela noção de divisão social do trabalho. As heterogeneidades que se colocam de modos diversos, a partir deste mesmo processo de reconhecimento das transformações que tiveram lugar no mundo contemporâneo, "tornam duvidosa a persistência de qualquer relevância sensível do trabalho remunerado dependente, enquanto tal, na percepção dos interesses sociais, na autoconsciência, no comportamento organizacional e político dos trabalhadores" (Offe, 1984, p. 20).

Nessa mesma linha de argumentação, torna-se importante perceber o descentramento da esfera do trabalho frente a outros âmbitos vitais. Referindo o trabalho a seu papel na organização da existência pessoal, Offe encontra duas alternativas: ou sua normatização como obrigação, ou sua instalação como imposição. A perda da validade e da centralidade subjetivas do trabalho teria que ser verificável em face dos processos que levaram ao colapso destes mecanismo. A desumanização das tarefas, gerada pelo taylorismo, jogou um importante papel nesse processo, pela eliminação das capacidades morais da produção. Na esteira dos acontecimentos de 68, ao longo dos anos setenta, afirma Offe, a força de trabalho se sensibilizou para as sobrecargas físicas e psíquicas do trabalho, para seus aspectos negativos e seus riscos, o que desencadeou uma indagação a respeito da substituição da luta por melhores condições de trabalho em favor da "luta contra o trabalho" (Offe, 1984, p. 27-30).

É óbvio que tais considerações não podem ser remetidas sem mediações à realidade do trabalho no Brasil, mas é significativo que, do ponto de vista internacional, a questão do direito ao trabalho venha sendo, ao mesmo tempo, reconhecida como utópica e criticada como excessivamente limitada, sobretudo quando contraposta à reivindicação do direito ao trabalho útil e significativo ${ }^{2}$. Offe aponta, a partir da crise da "sociedade do trabalho" - e, portanto, das categorias sociológicas que nascem dela e nela se referendam "a necessidade de cartografar as esferas da realidade social não plenamente determinadas pelo âmbito do trabalho e da produção" (Offe, 1984, p. 34), o que corresponderia a uma busca das estruturas, campos de ação e relações de sentido além da esfera do trabalho. Pela perda de sua capacidade de estruturar a sociedade, esta esfera teria sofrido uma "implosão de seu poder de determinação social", liberando "novos cenários de ação com novos atores e novas racionalidades" (Offe, 1984, p. 36) ${ }^{3}$.

A centralidade da categoria trabalho, suas dimensões e seu estatuto são um núcleo de discussão recorrente para a sociologia do trabalho desenvolvida na última década. Focalizar a atenção na discussão que vincula as dimensões do trabalho e as outras esferas e práticas sociais requer uma reflexão que questione a idéia da figura abstrata do trabalho e do trabalhador em sua "pureza" e autonomia, tal como foram tematizados pela sociologia clássica, ao pensar seu próprio tempo. Essa discussão exige que se 
RIZEK, Cibele Saliba. Interrogações a um campo teórico em crise. Tempo Social; Rev. Sociol. USP, S. Paulo, 6(1-2): 147-179, 1994 (editado em jun. 1995).

considere o trabalho humano em toda a sua complexidade, o que acaba por contemplar uma outra questão: as transformações que se geram a partir de outras concepções de trabalho oriundas de um campo teórico que tensiona suas configurações clássicas, na medida em que interroga a relação entre as dimensões do trabalho, suas categorias sexualmente neutras e as questões de gênero.

Cada vez mais, diante deste conjunto de interrogações parece ser impossível pensar nas unidades produtivas como mundos insulares cujas relações possam ser explicadas principalmente a partir de seu próprio interior. O "mundo fabril" visitado e revisitado pelas teorias do processo de trabalho, ao que tudo indica, não pode se esgotar ou se explicar por si mesmo. Os trabalhadores, igualmente, não são apenas trabalhadores higienizados e desodorizados pelo capital. São força de trabalho, sem dúvida, mas apenas diante e por obra do capital. São trabalho abstrato, são apenas trabalhadores em sua forma pura, mas essa talvez seja a forma de apreender e de encenar o que se constituiu como inédito e avassalador ${ }^{4}$.

Para compreender as idéias em confronto no momento em que se questionam tão fortemente as categorias clássicas, assim como as relações sociais que nelas estão configuradas, é necessário acompanhar os percursos que constituíram as leituras contemporâneas que acabaram por se aglutinar em uma sociologia do trabalho que, como se verá, produz mais indagações que respostas.

Uma das questões colocadas pelos achados de pesquisa é a impossibilidade de perceber ou de dissociar duas dimensões que se mostraram por todo o percurso de investigação, indissociáveis: a atividade do trabalho e a atividade das linguagens utilizadas para sua expressão, a atividade de representação do lugar e do papel da esfera do trabalho em suas vidas, naquilo que define estes trabalhadores para si mesmos. Essas dimensões não poderiam ser consideradas como instâncias separadas, desvinculadas de outras esferas da experiência. Ao contrário, são elas que, a todo momento, são chamadas para identificar o local e a atividade do trabalho. Na análise das entrevistas realizadas ao longo da pesquisa sobre os trabalhadores da Petroquímica União, ficou claro que os empréstimos metafóricos utilizados - uma empresa mãe, madrasta, esposa, prisão, bomba e labirinto - não são aleatórios. Mais do que isso, essas imagens, ao mesmo tempo estáveis e flutuantes ${ }^{5}$, fixam uma forma de apreensão e de apropriação de suas experiências. Fora da empresa, não são ninguém, como acentuam as falas recolhidas. Dentro empresa não são quaisquer trabalhadores, mas petroquímicos e também filhos, enteados, maridos, vítimas potenciais de contaminações e explosões, estão confinados, são denunciados por seus próprios instrumentos de trabalho, perdem-se no labirinto. Se estas "figuras de linguagem" não falam por si mesmas, no mínimo denunciam as muitas significações - tão "impuras" quanto a própria categoria força de trabalho, quando referida a estes trabalhadores - a partir das quais matizam sua lin- 
guagem, suas formas de apreensão de um "mundo fabril" que ao mesmo tempo se vê e se faz invadir pelas esferas privadas da vida. Mais do que isso, em empresas desse tipo, esse mesmo mundo fabril se constrói a partir de configurações advindas de padrões de gestão fincados em projetos sociais bastante claros $^{6}$, a partir dos quais não se constituem e nem poderiam se constituir relações de trabalho "puras", já que é a partir da própria concepção das gerências e da gestão que a empresa se erige na imagem da "grande família" " Imagens do passado no presente modernizador, imagens que podem se fincar quer no regime de patronage, quer em uma forma de gestão patriarcal, ambas de qualquer maneira distantes das formas gerenciais que se teceram a partir do que se pode considerar relações de trabalho características da modernidade. Mais do que isso, em outros cenários essa montagem poderia ser caracterizável como herança da produção artesanal, ou como formas arcaizantes, desviantes, portanto. Foram, entretanto, "desvios" necessários para a construção das rupturas que criaram a categoria trabalho em sua forma "pura" (cf. Ewald, 1986). No caso em questão - os trabalhadores da primeira central de matérias-primas petroquímicas do país - não há vínculo com o passado, mas com a construção de um presente que apelava, de um lado, para a configuração de uma força de trabalho estável, permanente e sem voz, dentro e fora das instâncias fabris. Por outro lado, essa privatização se estende à existência e às condições de trabalho e se faz fora do âmbito da construção da eficácia simbólica de direitos que estão presentes e, ao mesmo tempo, ausentes. Trata-se, portanto, de identificar duas formas que se entrecruzam na montagem dessas relações, que poderiam corresponder a dois registros em que se tecem a capacidade de contraposição e de resistência dos trabalhadores e, por outra via, a permanência de um tempo privado em que se constroem suas representações e imagens referidas às dimensões também privadas da vida. Assim, pode-se constatar a insistência e a força de representações imaginárias cuja construção só se desloca pela explicitação daquilo que são obrigados a rememorar, de vínculos denegados que são necessariamente obrigados a reconhecer, quando se afirma a necessidade de contraposição e de alteridade: na defesa da vida e na recusa ao trabalho ${ }^{8}$.

De um lado, caracterizá-los somente como força de trabalho significaria, necessariamente, deixar de perceber a importância dessas representações. De outro, a problematização de seus vínculos e das imagens enunciadas em suas falas, remete a uma outra dimensão tão necessária, quanto mais se reconhece que o padrão de gestão da empresa estudada tem como contrapartida necessária o não auto-reconhecimento de saberes, de direitos, de alteridades não assimiláveis à sua esfera. Esse padrão, por sua vez, não parece ser uma peculiaridade nem da produção petroquímica, nem apenas das empresas estatais 9 .

Há, entre outros, dois casos estudados - o da Companhia Siderúrgica Nacional e o da Fábrica Nacional de Motores - em que imagens e 
discursos semelhantes foram registrados. Entretanto, em ambos, não apenas se verificavam situações onde a associação fábrica-vila/cidade operária estiveram presentes ${ }^{10}$, como também, de modos diversos, as formas de encapsulamento e de militarização dos espaços e condições de trabalho, de certa maneira foram rompidas por movimentos sindicais e/ou fabris. Conflitos e confrontos acabam por romper as situações anteriores tal como foram descritas por estes estudos. Assim, semelhanças e diferenças constituem, em cada caso, especificidades que não devem ser menosprezadas. Para avaliar essas mesmas especificidades, mais uma incursão teórica foi necessária. Trata-se de rastrear a noção de consentimento, tal como foi (e ainda vem sendo) tematizada. No interior dessa discussão e por meio dela, a questão da subjetividade se anunciou como eixo de um conjunto de interrogações.

\section{Construção e crise de um campo temático}

Se as dimensões do trabalho na sociologia clássica são cruciais para a instituição de seu objeto, para a criação da sociedade como totalidade articulada, é inegável que foi sobretudo a partir de Marx que as dimensões do trabalho ganharam destaque, a ponto de se constituírem em objeto específico de um campo temático: a sociologia do trabalho.

É como se as contribuições da sociologia industrial, herdeira de Durkheim e Weber, tivessem ficado, por assim dizer, desde os anos setenta, postas de lado por abordagens de filiação marxista, para, pontualmente, serem retomadas, aqui e ali, a partir do que se configura recentemente como uma crise desse campo de reflexão.

Do ponto de vista das visões contemporâneas sobre a questão do trabalho, importantes modificações estão em curso, quer do ponto de vista das novas realidades impostas pela globalização econômica, pela transformação das bases técnicas de produção, terceirização, flexibilização, etc., quer porque, no bojo de uma crise dos projetos e concepções que marcam a modernidade, passa-se a repensar, à luz de um questionamento ou esgotamento teórico, as formas de explicação e configuração da realidade social das relações de trabalho. Alguns dos problemas e temas emergentes devem ser vistos mais de perto.

A partir de Braverman (1974), cujas contribuições foram inquestionáveis, colocaram-se como questões centrais do campo de uma sociologia do trabalho as práticas e formas de controle sobre o trabalho, já que "a função da gerência capitalista é a conversão da força de trabalho em trabalho, sob condições que permitam a acumulação do capital", e os processos de qualificação/ desqualificação (cf. Ramalho, 1991).

Os argumentos recentes que apontam para o esgotamento dessa teoria como forma de explicação da organização do trabalho nas sociedades capitalistas vêm se centrando na diversidade de interpretações sobre a relação de controle da gerência sobre os trabalhadores. Littler, por exemplo, con- 
sidera que a relação hierárquica se transformou em elemento estrutural, já que faz parte da geração constante de mais-valia. As atividades de pressão das gerências "afetariam os interesses econômicos e sociais dos trabalhadores que em consequiência resistiriam ao controle" (Ramalho, 1991, p. 32).

Thompson, por sua vez, encara a relação de controle como uma relação dual, colocada pelo dilema que se trava entre tratar ou não tratar o trabalho como mercadoria. A mera troca econômica não seria suficiente para caracterizar a relação entre gerentes e operários, já que, diante da necessidade do capital de revolucionar constantemente a produção e, portanto, alterar dentro dela o papel do trabalhador, ele não pode confiar apenas no controle e na coerção. Assim, em algum nível, a adesão, a cooperação, a capacidade de criar, portanto, o consentimento dos trabalhadores precisa ser utilizado ${ }^{11}$.

Se o processo de trabalho é constitutivo de relações bastante contraditórias, estas contradições, entretanto, não se restringem apenas às relações capital-trabalho. Se há resistência à subordinação e à exploração, também se verifica - sobretudo com as transformações recentes, diante das quais o próprio emprego é visto como uma situação privilegiada - o interesse dos trabalhadores na manutenção das relações econômicas existentes e na viabilidade das unidades de capital que os empregou. Isso implica a existência de uma interação fragmentada de controle, consenso e negociação.

Nesse sentido, autores como Burawoy insistem na necessidade de compreender que, para além dos enfoques que privilegiam o conflito ou a harmonia, "o processo de trabalho deve ser entendido não apenas em termos de conflito e resistência, mas também em termos de geração de consentimento" (Ramalho, 1991, p. 32), já que os interesses que organizam o cotidiano dos trabalhadores não são unívocos nem podem ser imputados. Ao contrário, são produzidos e reproduzidos de formas particulares. Assim, crer a priori que os interesses do capital e do trabalho são antagônicos acaba por turvar a compreensão do controle capitalista, pois menospreza-se a esfera ideológica na qual esses mesmos interesses se fazem representar. Faz-se necessário, portanto, desenvolver uma teoria que possa investigar as condições nas quais os interesses do trabalho e do capital se tornam antagônicos. O fenômeno a explicar não se centra na eventual explosão da resistência operária, mas exatamente no seu inverso. Assim, para o conjunto destes autores, apesar das diferenças de enfoque entre eles, resistência e consciência de classe não são dados, o que deve conduzir à necessidade de investigar tanto as relações gerência/trabalho em suas condições concretas, atuais e particulares, como atitudes e práticas dos trabalhadores ${ }^{12}$.

As críticas a Braverman, só para citar um debate que ocorreu em uma bibliografia de língua inglesa, apontavam para a necessidade de reconsiderar os índices e a qualidade da participação dos trabalhadores na sua esfera de ação no interior da fábrica. Algumas noções podem e devem ser 
RIZEK, Cibele Saliba. Interrogações a um campo teórico em crise. Tempo Social; Rev. Sociol. USP, S. Paulo, 6(1-2): 147-179, 1994 (editado em jun. 1995).

citadas. O conceito de "estratégias gerenciais" de Friedman opera com os pressupostos de que, em primeiro lugar, o trabalho e os trabalhadores são extremamente maleáveis, na medida em que o conteúdo do trabalho não precisa ser contratualmente especificado. Além disso, os trabalhadores seriam controlados por uma vontade que é, em geral, hostil à gerência. Disso decorrem dois modelos de estratégia gerencial: "autonomia responsável" e "controle direto". Ambos carregam uma contradição fundamental na qual se assentam e se estabelecem tanto a situação como o imaginário dos trabalhadores: liberdade formal, de um lado, e alienação de sua força de trabalho, de outro, liberdade murada e vigiada que insiste em diferenciar o estatuto da fábrica do espaço de prisões.

Os dois modelos de gestão distinguem-se, para Friedman, basicamente pelo fato de que, na estratégia de controle direto, os trabalhadores são concebidos como máquinas, ao passo que a estratégia de autonomia responsável os trata como alvos de um convencimento em torno de uma comunhão de objetivos com os da própria gerência. Particularidades inerentes a cada situação com relação ao mercado de bens e de trabalho poderiam influenciar nas escolhas das estratégias gerenciais, relativamente a grupos de trabalhadores ou diferentes unidades da mesma em empresa, de acordo com a região do país em que se encontram estas unidades e mesmo de acordo com situações nacionais centrais ou periféricas. Assim, a chave para explicar por que o local de trabalho, ainda hoje, é controlado pelos gerentes reside no fato de que é o controle, mais do que a eficiência que gera maiores lucros. Esta habilidade dos capitalistas e gerentes de obter um comportamento desejado no trabalho compõe um sistema constituído pela divisão das tarefas, avaliação e supervisão, e disciplina (Ramalho, 1991, p. 34).

Ao capitalismo competitivo corresponderiam um "controle simples" e duas de suas variantes: o controle empresarial (através do carisma pessoal de um proprietário) e o "controle hierárquico" que supõe uma cadeia unívoca de comando e pode implicar uma militarização empregada em grandes organizações como na indústria de ferro e aço. No capitalismo monopolista, concomitantemente a um aumento do poder de mercado das empresas, há um aumento da resistência operária contra o poder arbitrário dos mestres. Com isso, as empresas aprenderam a submeter a própria gerência ao controle gerencial, aprenderam a institucionalizar canais de reivindicação, aprenderam, enfim, a utilizar e a criar um "governo pela lei". Assim, o capitalismo monopolista monta um "controle estrutural" (controle técnico embutido no mecanismo de controle da estrutura tecnológica da empresa, combinado com o controle burocrático, embutido na sua estrutura sócio-organizacional). Com a informatização do processo de trabalho, os mecanismos de avaliação e supervisão podem ser incorporados ao controle técnico, ao qual, entretanto, escapa um elemento fundamental: a disciplina. A burocratização das formas de controle, ocorrida após 1930, instaura o 
terreno das regras impessoais, das leis da empresa, rotinizando as funções e os procedimentos da gerência, estratificando o trabalho, impondo compromissos e estabelecendo normas de promoção. Muda, portanto, a alocação do controle e da forma de controlar, que se institucionaliza, abrangendo, inclusive, as esferas de conflito. Ainda segundo Edwards, o controle burocrático tem um caráter difuso, tendendo a abranger um maior número de aspectos da vida e do comportamento dos trabalhadores. É dele que emanam as sanções positivas que atribuem benefícios para trabalhadores responsáveis e confiáveis, no que se poderia denominar "hierarquia graduada".

Burawoy, por sua vez, parte da constatação de que, no capitalismo, os tempos de trabalho necessário e excedente não estão separados. Segundo ele, não seria possível se certificar de que o excedente de trabalho tenha sido realmente alcançado. Ou seja, a dinâmica do modo capitalista de produção obscurece a extração de mais-valia tanto para o trabalhador quanto para o capital. Uma de suas críticas centrais a Braverman dirige-se ao papel que este atribui ao taylorismo. Para Burawoy, Braverman toma uma simples expressão do controle capitalista como a sua essência, já que a extração de mais-valia, a um só tempo assegurada e obscurecida, requer um domínio que vai além do econômico, perpassando também as esferas políticas e ideológicas. Burawoy coloca, a partir de seus estudos empíricos em uma fábrica americana, a noção de "jogo" pelo qual se expressa o "consentimento" ativo dos trabalhadores às relações capitalistas de produção ${ }^{13}$. Este consentimento ativo se funda na premissa de que as atividades de trabalho, ainda que restritas, oferecem aos trabalhadores escolhas reais. "O jogo é constituído de regras informais com o objetivo de criar espaço e tempo, controlar ganhos e tornar o trabalho mais interessante (...) o jogo pode surgir de iniciativas dos trabalhadores, mas é regulado (coercitivamente se necessário) pela gerência" (Ramalho, 1991, p. 36).

Por meio deste jogo, investido de uma dinâmica própria, legitimam-se as condições do trabalho capitalista. Essa legitimidade produzida pelo consentimento pode abranger, inclusive, o uso da coerção e da força, o que independe de fatores externos como escola, religião ou família, bem como das condições de mercado. Essa independência é caracterizada como autonomia relativa do processo da produção que "pode determinar, por si mesmo, o efeito da consciência importada de fora" (Burawoy, 1982, p. 152). Assim, a consciência que se forma no local da produção passa a traduzir "as relações na produção (a organização das tarefas de trabalho) em atividades que geram consentimento" (Ramalho, 1991, p. 37).

É mediante a experiência vivida e nela mesma, diz Burawoy, que se produzem ideologia e interesses. Nem um nem outro podem ser pensados como dados. Assim, para este autor, qualquer distinção entre fatores objetivos e subjetivos é arbitrária. Dessas considerações nasce um diálogo crítico com a teoria marxista clássica, em especial no que se refere à classe "em si" e "para si". Contra o que considera homogeneizador na concepção 
RIZEK, Cibele Saliba. Interrogações a um campo teórico em crise. Tempo Social; Rev. Sociol. USP, S. Paulo, 6(1-2): 147-179, 1994 (editado em jun. 1995).

marxista de luta de classes, Burawoy constrói a noção de regime de produção, como instância de mediação entre a classe em si e a classe para si. "Sua forma determina como e se a classe em si vai resultar em classe para si" (Ramalho, 1991, p. 38).

A noção de regimes fabris, por sua vez, dá origem a uma tipologia que se compatibiliza com as diferentes fases do capitalismo: regimes despóticos (com base na coerção) e regimes hegemônicos (com base no consentimento e equilíbrio de poder, no qual a gerência fica impedida de impor controles autoritários típicos dos regimes despóticos), além de um terceiro tipo, o "despotismo hegemônico", possível pela atual vulnerabilidade coletiva dos trabalhadores à mobilidade nacional e internacional do capital. $\mathrm{Ou}$ seja, os trabalhadores enfrentam a perda de seus postos não como indivíduos, mas em consequiência das ameaças que incidem sobre a viabilidade econômica das empresas, o que geraria um sacrifício consentido.

Os textos que se referem diretamente à discussão do campo da teoria do processo de trabalho apontam que esta teoria se encontra em meio a uma crise que pode ser identificada com as indagações feitas em relação às suas falas fundadoras - quer elas venham de Braverman ou Burawoy - e que, por essa via, são tributárias das leituras e "atualizações" que fazem das noções teóricas de Marx (Knights \& Willmot, 1990).

Uma primeira questão que pode ser encontrada tanto no debate travado entre diversos autores, como nos comentaristas deste debate ${ }^{14}$ refere-se à possibilidade e à verificabilidade de uma correspondência entre as fases históricas do capitalismo e as formas que assume o processo de trabalho. A questão se apresenta desde Braverman e perpassa a construção de várias tipologias, tal como se pode verificar em Friedman - em relação ao que esse autor chama de estratégias gerenciais -, Edwards - e as formas que assume o sistema de controle - e Burawoy, no que diz respeito aos regimes fabris. Esta mesma questão acaba por questionar de várias maneiras a própria construção de modelos e tipologias como formas de explicação. A primeira e mais evidente diz respeito a uma confusão, apontada por Littler (1990) principalmente, entre formas de controle muito específicas e tendências muito gerais. $\mathrm{O}$ uso de tipologias como ferramentas teóricas pode, assim, não se configurar em instrumento adequado para captar a historicidade das relações de trabalho e de suas práticas, confundindo-se com uma caracterização por demais ampliada das grandes fases históricas do capitalismo, o que obscurece, mais do que explica, situações diferentes, concretas e específicas.

Como aponta Ramalho, o debate contemporâneo dirige parte significativa de sua atenção para as dimensões e formas do controle sobre o processo de trabalho, enriquecendo e diversificando o conceito de Braverman sobre o taylorismo como essência do controle capitalista sobre os trabalhadores e suas tarefas. Neste sentido, vários autores vão buscar reconceituar criticamente as formas de controle - gerencial ou não - como Littler, Edwards 
e Burawoy. O primeiro considera a necessidade de ir além de uma dialética simples de controle e resistência destacando a importância dos componentes sociológicos e políticos das formas de controle, bem como das mediações que se estabelecem a partir do mercado de trabalho e das formas estatais de regulação. O segundo tenta diferenciar "controle detalhado" e "controle geral" e chega à noção de "fronteiras de controle" que, por assim dizer, contem e resume formas de gerenciamento da força de trabalho e formas de resistência passadas, construindo os horizontes futuros de relação entre gerências e trabalhadores. O terceiro, por meio da noção de regimes fabris e das suas importantes considerações a respeito da geração de formas de consentimento através dos jogos, acaba igualmente por questionar a contraposição controle/resistência.

São ainda numerosas as passagens desse debate que, ao indicar uma crise na teoria do processo de trabalho, acabam por questionar a sua especificidade teórica, bem como a dificuldade em delimitar-lhe um objeto, ou mesmo as inconsistências desta delimitação, em um diálogo crítico com Braverman e sua leitura de Marx. Littler se torna um exemplo desse tipo de crítica ao apontar o que entende como uma insuficiência das ferramentas teóricas de Marx e das leituras de Marx para dar conta dos processos de trabalho mediados e vinculados, de um lado, às dimensões tecnológicas e de ação gerencial e, de outro, ao mercado de trabalho, ação do Estado, etc. Essas mediações e vinculações estariam, assim, associadas ao que ele chama de ciclos longos ou circuitos completos do capital (Littler, 1990).

Uma outra fonte de críticas bastante interessantes, surge da idéia de que o campo da teoria do processo de trabalho está permeado por três grandes fantasmas: o funcionalismo, o determinismo e o essencialismo. Thompson cita como exemplo a idéia de uma conspiração indiferenciada do capital, capitalistas e gerentes e sugere a dificuldade em especificar o objeto de uma teoria do processo de trabalho, o que conduziria a uma dificuldade em delimitar a própria teoria e seu alcance. A questão é que o processo de trabalho, percebido como setor específico de estruturas e práticas, interage com outras análises e outras práticas que nascem e se constituem a partir de outras relações sociais. A empresa capitalista seria, portanto, ponto de intersecção de campos e práticas diversas. Thompson indica ainda a necessidade de perceber que não há automatismos ou determinismos rígidos na relação entre processo de trabalho, classe, dinâmica de classe e transformação social, identificando um buraco negro teórico para o qual o marxismo não ofereceria ferramentas conceptuais suficientes: a ausência de sujeitos, a produção e reprodução de identidades sem sua vinculação automática à idéia de telos ou finalidade. Estas considerações levam-no a problematizar os vínculos entre luta de classes, controle e resistência, bem como à idéia de classes como lugares vazios e/ou no sentido estrutural clássico (Thompson, 1990).

Contrapondo-se à ênfase na intersecção do processo de trabalho 
com outros campos, estabelecidos a partir de outras relações sociais, Edwards destaca a historicidade das relações de trabalho em sua autonomia relativa em face de outras esferas da sociedade. Ressalta ainda a necessidade de se pensar em uma negociação da ordem, bem como de requalificar as dimensões do controle (detalhado e geral) do conflito, referido, de um lado, ao que este autor chama de "antagonismo estrutural" e, de outro, ao consentimento pensado como dimensão produzida por jogos que acabam gerando legitimidade, tal como afirma Burawoy.

Knights, por sua vez, trabalha exatamente naquilo que Thompson caracteriza como o buraco negro da teoria do processo de trabalho - sujeitos e subjetividades - na tentativa de superar os dualismos que perpassam as análises que se vinculam ao objetivismo ou ao subjetivismo. Para ele, só um conceito mais adequado de sujeito poderia levar a uma superação da crise da teoria do processo de trabalho. As possibilidades de construção desta noção estariam obscurecidas pelo que o autor chamou de voluntarismo e pelas preocupações dos autores de filiação marxista com a dialética. A dificuldade diz respeito exatamente à construção de uma noção de sujeito e de subjetividade não-essencialistas (cf. Knights, 1990) ${ }^{15}$. Menciona ainda inúmeras formas por meio das quais as dimensões da subjetividade são reduzidas à capacidade de resistência, de criação e de produtividade ou à dinâmica da cooperação e conflito, ou, ainda, às distorções ideológicas referidas aos interesses reais. Diante do que designou como "miopia da teoria do processo de trabalho em relação ao sujeito" (quer nas considerações relativas à busca de um sujeito autônomo, quer no que se refere a pensar estruturas independentemente de seus processos de constituição através de sujeitos e práticas), Knights destaca dois autores que reconsideram, ainda que com limitações, a questão do sujeito na teoria do processo de trabalho. O primeiro é Burawoy, que se refere a um processo de auto-organização dos sujeitos por meio de jogos nos chãos das fábricas. O segundo é Cockburn, através de sua análise de gênero.

As críticas de Knights a Burawoy, apesar do reconhececimento que não há propriamente uma redução da subjetividade a atitudes e orientações em relação ao trabalho, são as mesmas que podem ser dirigidas a Marx e Braverman, isto é, são críticas às dimensões essencialistas da natureza humana. Por outro lado, ainda segundo Knights, a análise de Burawoy não teria considerado as práticas que se constroem a partir da redução das incertezas que rondam os sujeitos - trabalhadores e gerentes -, já que na institucionalização dos processos de trabalho ocorrem, ao extremo, os mecanismos de individualização e disciplinarização que permeiam as instituições. Além disso, as dimensões relativas às questões de gênero também estariam ausentes.

Em relação a Cockburn, Knights critica especialmente sua visão de uma identidade masculina como compensatória em relação à diminuição ou falta de poder em relação ao trabalho e ao capital (o trabalhador 
se torna pequeno perante o capitalista, e por isso mesmo tem que ser grande em relação ao lar e às mulheres). $\mathrm{O}$ autor considera, assim, que o ponto a criticar tanto em Burawoy como em Cockburn é seu dualismo: subjetividade $e$ poder no primeiro caso, classe $e$ gênero no segundo. É importante, entretanto, situar a perspectiva a partir da qual este autor fala. Knights apela para o enfoque teórico que nasce a partir de sua leitura de Foucault, para se contrapor aos autores da teoria do processo de trabalho. É a partir de Foucault que propõe um núcleo de reflexões "nãoessencialistas" a respeito do processo de construção de subjetividades e identidades vinculadas às dimensões de uma outra concepção de poderes e saberes disciplinares ${ }^{16}$.

Além da excelente sistematização de Ramalho, que organiza as questões que hoje estão colocadas para o debate anglo-saxão, o texto de Guimarães e Castro centrado nesse mesmo debate busca um questionamento da noção de modelos que, se originariamente podem estar referidos à construção típico ideal, freqüentemente são tomados como "modeladores do real". Por meio de um contraponto com o "modelo japonês", os autores - que perpassam criticamente Braverman, Burawoy e Knights - enfatizam, a partir de Hirata e Zarifian, o âmbito das relações sociais e simbólicas que se tecem na área de intersecção entre cultura operária, cultura de empresa e cultura nacional (Castro \& Guimarães, 1991).

Várias outras questões podem ainda ser colocadas a partir destas considerações. A primeira origina-se nas abordagens desenvolvidas na França, vinculadas à preocupação de compreender as instâncias subjetivas dos trabalhadores. Deste ponto de vista, a obra de C. Déjours é paradigmática. Para os que se vincularam a uma psicopatologia (ou, mais recentemente, a uma psicodinâmica) do trabalho, as dimensões subjetivas só podem ser vistas e pensadas a partir de individualidades ${ }^{17}$. Outros enfoques dessas dimensões subjetivas nascem de uma associação que pode ser pensada como redução: os aspectos subjetivos das realidades e práticas que permeiam os mundos do trabalho são assimilados ao universo da consciência de classe, ao mundo das representações ideológicas, no sentido clássico de sua concepção. Ora, as dimensões subjetivas são realmente tramadas e construídas de maneira decisiva e relativamente autônoma no mundo do trabalho ou no chão-da-fábrica, como quer Burawoy? Pode-se considerar a construção de subjetividades de forma tão segmentada? Mais do que isso, quais são as matrizes pelas quais essas subjetividades são pensadas? Uma delas advém da idéia de que é subjetivo tudo o que se contrapõe às esferas objetivadas da produção e das relações sociais. Outra refere as dimensões da subjetividade à construção de identidades, o que pode pressupor uma lógica unitária, difícil de ser construída e sustentada. A recusa dessas matrizes poderia ser pontuada por algumas questões oriundas de indagações formuladas por Zarifian que considera necessário abandonar a idéia de que o trabalho poderia se definir, princi- 
palmente pela atividade exercida.

"Pois a atividade é nada mais que o índice, a forma objetivável do trabalho em um momento dado, em uma situação produtiva particular (...) Isso não diz rigorosamente nada sobre o que levou esta situação a existir precisamente sob essa forma. Fala-se sobre o que há no trabalho concreto, mas nada se diz sobre o que o trabalho é, sobre o que o determina a ser de uma certa maneira (e o trabalho não existe 'em geral', ele existe sempre de uma certa maneira). Fixando-se sobre a atividade (...) corre-se o risco de objetivar a subjetividade, de supor que uma certa subjetividade em curso na atividade possa ser objetivada, tratada como um objeto cujos princípios gerais de funcionamento seriam, de toda sorte, descritos. É em nome dessa subjetividade-objeto, dessa subjetividade geral, atemporal, sem determinações sociais explícitas, que se poderia afirmar, por exemplo, que o trabalho pré-definido não é verdadeiramente trabalho, porque ele trai uma disposição genérica e geral do sujeito humano que reside na livre vontade de dispor de si (precisamente o que Locke dizia)" (Zarifian, 1993).

Além dos problemas levantados pelo debate anglo-saxão, outro conjunto interessante de questões nasceu da discussão do taylorismo, fordismo, fordismo periférico e pós-fordismo quer em textos diretamente vinculados à sociologia do trabalho, quer naqueles que têm por origem um campo interdisciplinar que se origina da teoria da regulação, ainda que esses conceitos tenham âmbitos distintos. Essa diversidade de espectro conceitual, freqüentemente impôs a necessidade de explicar em que sentido foram utilizadas essas categorias ${ }^{18}$. A questão da caracterização do fordismo e pósfordismo gerou uma série de discussões que se centram na "especialização flexível", por sua vez, duplamente referida às esferas empresariais, em suas dimensões técnicas e de gestão, e às políticas sociais vinculadas à crise do Estado do Bem-estar Social, onde ele chegou a existir. É preciso notar que, em meio a uma crise conceitual, buscou-se mais uma vez uma aproximação com um conjunto de conceitos cuja importação se faz - freqüentemente de forma pouco elucidadora - de um âmbito teórico que teve origem na combinação do marxismo com o keynesianismo (cf. Oliveira, 1992).

A questão da especialização flexível ou da flexibilidade, pelo menos no âmbito dos processos de trabalho, implica desde a gestão dos estoques, gerenciamentos poupadores de mão-de-obra, através da subcontratação, até novas tecnologias, novos patamares de qualificação, alteração das linhas de clivagem entre trabalhadores e gerentes, trabalhadores contratados e subcontratados, alterações constantes do processo e dos postos de trabalho, busca de otimização e de identidade entre o trabalho prescrito e o trabalho real, etc. Entretanto, a construção de tipologias dos regimes de acumulação e/ou modelos de desenvolvimento pode, pelo menos, criar tantos problemas quanto os que resolve, especialmente se essa tipologia é utilizada para, sem mediações, explicar a diversidade do universo empírico com o qual é possível se defrontar em países como o Brasil. 
A flexibilização, inovações tecnológicas pela substituição da base técnica eletro-eletrônica pela microinformatização - e globalização foram de grande impacto na reflexão sociológica a partir dos anos oitenta. Uma destas questões parece não ter sido concluída: a investigação das dimensões que, nesta "nova" forma de tratar o trabalho, dizem respeito ao saber operário em suas múltiplas faces, questão, aliás, clássica no campo da sociologia do trabalho.

O que está ocorrendo com a qualificação, em meio a um conjunto importante de transformações? A questão não pode ser reduzida ao binômio mais/menos, quantidade/qualidade de trabalhadores qualificados, entre outros motivos, porque a discussão dos saberes e de sua significação está colocada como pano de fundo de uma diferença importante que se localiza nas significações que a qualificação tem para as empresas e para os trabalhadores, para homens e para mulheres, para trabalhadores do setor metalmecânico e para os que se vinculam a indústrias de "processo contínuo", ou indústria de propriedade ${ }^{19}$.

É possível, ainda, pensar no aprofundamento da heterogeneidade produzida e reproduzida pela dinâmica recente das tendências da globalização. Se, de um lado, é verdade que há processos cuja implantação parece obedecer a uma lógica já dada, de outro, também é verdade que sua realização está matizada pela presença - e pela capacidade de fazer valer essa presença - dos trabalhadores e de suas lutas na dinâmica de transformação. Assim, a aparição pública dos trabalhadores nessa cena, ainda que um conjunto de tendências articuladas em um processo de reestruturação produtiva possa parecer inexorável, é uma diferença que certamente conta, que certamente muda o que pode se afigurar como "a ordem natural das coisas" ${ }^{20}$. Evidentemente, como sugere Freyssenet (1989), esse comentário pode se referir, entre outros aspectos, à dinâmica da qualificação, bem como ao seu reconhecimento patronal.

Outros aportes sobre a questão da qualificação, questionada ou revisitada à luz das transformações em curso, tem instabilizado suas significações. Tradicionalmente, a discussão da qualificação operária apresenta um quadro instantâneo do emprego em que diferentes processos se confundem como se não tivessem durações diferentes - isto é, tudo se passaria como se as dimensões da qualificação dos trabalhadores fossem identificadas a uma substância, a uma qualidade em si. Tentando escapar destas abordagens, P. Rolle propõe uma série de perguntas sobre os conceitos tradicionais de qualificação. O que a define? Autonomia, maior esforço intelectual? Importância relativa de sua função? Ao comparar diferentes postos de trabalho o autor conclui que os equívocos e paradoxos da concepção clássica de qualificação advêm da suposta correspondência imediata entre os diferentes elementos que compõem a situação de assalariamento, o que confunde a evolução do trabalho e do trabalhador (Rolle, 1989, p. 86).

Remetendo a questão para outros campos, como, por exemplo, a 
RIZEK, Cibele Saliba. Interrogações a um campo teórico em crise. Tempo Social; Rev. Sociol. USP, S. Paulo, 6(1-2): 147-179, 1994 (editado em jun. 1995).

transmissão social de conhecimentos, introduz a dimensão de tempos diferentes, que incluem a dinâmica familiar, os investimentos em educação, etc., de forma que o "processo de formação tem, por unidade última, o tempo de uma vida inteira de trabalho, e se desenvolve ligando, uma a outra, gerações assalariadas inteiras" (Rolle, 1989, p. 86). Mais uma vez, desestabilizam-se os enfoques que circunscrevem os âmbitos de análise do processo de trabalho à empresa, às dimensões exclusivamente fabris.

Essa discussão pode ainda ser enriquecida com contribuições de Zarifian, que considera insuficiente pensar a qualificação como uma dimensão reduzida à posse de um estoque de conhecimentos - saberes, savoirsfaire, ou savoirs-être, que seriam utilizados na atividade profissional. $\mathrm{O}$ termo "competência", utilizado em substituição à qualificação, designaria, sem deixar de supor um conjunto de saberes, duas dimensões: a capacidade do trabalhador de fazer frente a situações industriais, em parte imprevisíveis, ou novas, para além de qualquer prescrição de seu trabalho; e a possibilidade de ser reconhecido como expert pelo julgamento dos outros, merecendo, assim, confiança. Dessa maneira, a competência não é somente uma questão de qualificação, mas também de organização, já que é ela que deve favorecer este reconhecimento. Haveria, assim, relações complexas entre competência e formação profissional, que dizem respeito àquilo que se pode chamar de aprendizagem, como também à natureza da organização. Distinguem-se, portanto, aprendizagem e experiência, já que a primeira supõe a capacidade de transferência do que se aprendeu para a resolução de situações inéditas (Zarifian, s/d). Essa abordagem interessante desloca os parâmetros tradicionais de formação e experiência para a esfera das relações do coletivo dos trabalhadores com as empresas, que passam a ser pensadas, do ponto de vista dos processos de qualificação, não mais como quem oferece cursos ou promoções, mas como instância que sanciona ou não o desenvolvimento da competência.

A discussão da questão da qualificação se intensifica a partir das formas de instabilização das tarefas e condições de trabalho durante os anos oitenta, em especial a polivalência ${ }^{21}$. O termo se refere a uma forma particular de organização do trabalho contraposta às formas clássicas, baseadas no princípio da especialização. Nos últimos vinte anos, aproximadamente, a polivalência vem se constituindo como uma alternativa à organização taylorista do trabalho e a seus "gritantes elementos disfuncionais" (cf. Dadoy, s/d). O princípio da polivalência supõe, no campo da organização do trabalho, a possibilidade de atribuir a um homem, de maneira alternada ou sucessiva, tarefas diferentes, postos de trabalho diferentes, funções diferentes, contra o princípio um homem, uma tarefa, um posto de trabalho. De qualquer forma, ela está historicamente vinculada à resolução das crises da organização do trabalho do fim da década de sessenta e início da década de setenta. No Brasil, assim como no âmbito internacional, a polivalência surge como iniciativa patronal no sentido da flexibilização dos sistemas de 
trabalho, em face da redução de emprego e das condições de rigidez que essa redução impôs, bem como das necessidades de "adaptação", com um menor efetivo de força de trabalho, às novas condições de um mercado cada vez mais globalizado. Assim, a situação que se descreve com a expressão polivalência é sempre percebida com base em uma posição anterior de especialização. Além disso, ela vem acompanhada do que os próprios trabalhadores identificam como um uso mais intensivo de sua capacidade de trabalho. Freqüentemente, associa-se, ainda, a inovações tecnológicas importantes e altera o quadro de especialização, embora não se possa afirmar que ela suponha um maior domínio dos trabalhadores nas esferas de concepção de seu próprio trabalho. Se hoje o termo polivalência é discutível, não há como negar que gerou um conjunto de interrogações em relação à qualificação nos anos oitenta, em especial no que se refere às resistências dos trabalhadores no chão-de-fábrica ${ }^{22}$.

Se as recentes transformações nos postos de trabalho, bem como na qualificação requerida para o desempenho dos trabalhadores, apontam para um presente transformado e colocam questões para o futuro do trabalho, a discussão da qualificação se enriquece, ainda, em confronto com a historicização e, portanto, a desnaturalização da divisão sexual do trabalho.

As interpelações ao feminino abalaram algumas certezas a respeito dos papéis no assalariamento e na família que não mais aparecem "como produto de um destino biológico, mas como um constructo social". A atividade do trabalho foi também requestionada em busca de uma definição mais ampla que levasse em conta "simultaneamente tanto o trabalho doméstico quanto o trabalho assalariado" (Kergoat, 1989, p. 89)23.

Disso decorre uma crítica às clássicas formulações que atribuem às mulheres um lugar de mão-de-obra desqualificada, exército industrial de reserva, espécie de refugo mobilizado apenas quando é necessário. Onde se via uma formação nula ou mal adaptada, constata-se "uma formação perfeitamente adaptada aos empregos industriais que lhe são propostos", adquirida por um aprendizado (a profissão de futuras mulheres) e, em seguida, por uma "formação contínua" (trabalhos domésticos). Assim, "as mulheres não são operárias não qualificadas ou ajudantes porque são malformadas pelo aparelho escolar, mas porque são bem formadas pelo conjunto do trabalho reprodutivo" (Kergoat, 1989, p 89).

Esse fato tem consequiências relevantes. A primeira é a origem das qualificações femininas, já que elas não são adquiridas pelos canais institucionais e, nessa mesma medida, podem ser negadas pelos empregadores. Assim, pode-se legitimar o não-reconhecimento das qualidades que lhes são exigidas, transformado-as em "atributos naturais" de gênero. Esse mesmo não-reconhecimento pode também permear o emprego masculino quando a qualificação do trabalhador não passa por canais institucionais que a legitimam. Outra conseqüência dessa discussão vem da banalização 
interiorizada do trabalho feminino, cujos saberes se constroem na esfera privada, sendo representados como aquisições individuais e não coletivas (Kergoat, 1989, p. 94-95). É possível observar, entretanto, que essa mesma banalização pode ocorrer com trabalhadores cuja qualificação advém, especialmente, não da escolaridade formal, mas de sua própria experiência de trabalho, guardadas as especificidades relativas ao gênero ${ }^{24}$.

As questões que se referem à dinâmica da qualificação e da desqualificação, percebidas nas falas e na observação das trajetórias dos trabalhadores entrevistados, colocam problemas interessantes em relação a esse inventário de posições. De um lado, até mesmo pelas promoções por tempo de trabalho que se transformavam nas mudanças da faixas salariais pode-se notar uma valorização da experiência de trabalho, principalmente porque ela fornecia a capacidade de intervir nos momentos de imprevisibilidade do processo. De outro lado, essa mesma experiência geradora de saberes particulares e raros no mercado de trabalho vinha, ao longo dos anos oitenta, se instabilizando pela mudança, ainda que lenta, da base técnica. Saberes se transformam em "vícios". As relações entre instrumentistas e operadores, chefes e subordinados, são cada vez mais precisamente codificadas por mediação de instrumentos e microcomputadores. Além das grandes diferenças entre instrumentistas e operadores, além das diferenças que perpassam setores e níveis (como por exemplo, a passagem entre o operador de campo - nível I - e o de painel - nível II), nota-se a ausência do auto-reconhecimento dessa experiência que fundamenta e embasa sua qualificação, ausência que se fez sentir não só pelo medo de perda do emprego, assim que foram implantados os novos sistemas de controle microeletrônico de processos, mas também pela impossibilidade de utilização dessa qualificação - que supunha a aquisição de um saber pouco transferível de forma imediata - como trunfo de negociação. Ao que tudo parece indicar, essa banalização da experiência dos trabalhadores só se quebrou por um reconhecimento que se manifestou quando, nos tribunais, foram considerados, por peritos e juízes, qualificados para depor sobre as condições efetivas de funcionamento da empresa.

Deste grande conjunto de questões que se colocam para os estudos e reflexões sobre o trabalho, algumas discussões merecem destaque. A primeira delas se refere aos aspectos que algumas das abordagens contemporâneas classificam como subjetivos. Esses mesmos aspectos podem ser pensados, até mesmo sem que se transformem as dimensões subjetivas em instâncias objetiváveis, como aponta Zarifian, através de outros registros, a partir dos quais adquirem outras configurações. Podem ser referidos a instâncias simbólicas e culturais forjadas na linguagem, nos universos familiares e de moradia, nas formas de apropriação da cidade, nos circuitos de um mercado cultural, etc. Mais ainda, formas extremamente "modernas" de gestão, compatíveis com a flexibilização das relações de trabalho, ou com as novas formas de caracterização das "parcerias" entre trabalho e capital, 
podem se construir através da apropriação de referências culturais, imaginárias ou simbólicas, fortemente vinculadas ao mundo privado, como a família e seus códigos de comportamento, ou mesmo referências extraídas do mundo de sinalizações afetivas e morais que envolvem o universo familiar, as relações de gênero que se geram a partir de uma elaboração extra-fabril.

A construção das subjetividades dos trabalhadores pode se constituir, assim, a partir de domínios distantes da empresa, mesmo que nela elas acabem encontrando formas de expressão dentro e para além do âmbito estrito de suas tarefas. Além disso, não há subjetividades que não estejam referidas a sujeitos e seu processo nada linear de construção, o qual vem sendo apreendido a partir de matrizes teóricas distintas. Algumas delas, encenam a possibilidade de se pensar sujeitos e subjetividades a partir de um discurso que enuncia o direito de dizerem-se a si mesmos, ainda que a fala do outro esteja presente, já que por meio dela, ultrapassando seus limites, permanece possível a construção de uma fala própria, de sua própria palavra. Se não se pode deixar de reconhecer que há uma crise da própria noção de sujeito, também não se pode ignorar que, de muitas formas e a partir de estruturas discursivas extremamente instáveis, a fala dos trabalhadores, que articula e se articula em suas práticas, pode e deve ser ouvida como fala própria, a partir da qual se fazem presentes (ou não) outros discursos, discursos do outro, quer ele seja o gerente, o técnico, o patrão ou o Estado $^{25}$.

Nas imagens dos trabalhadores petroquímicos sobre a empresa e sobre sua experiência de trabalho, pode-se, sem dúvida constatar esse ponto de intersecção entre práticas de natureza diversa, o que remete a uma outra temática: o lugar da fábrica tal como foi construído historicamente no Brasil, sua publicização pela lei e pela regulamentação do Estado, seu caráter privado não só como forma de propriedade, mas como lugar de ocultamento e invisibilidade, como espaço murado e separado do mundo por portões que não podem ser transpostos por qualquer um. Qual foi e como se altera no tempo o estatuto de cidadania de um trabalhador dentro destas instituições onde controle e disciplina se combinam com uma liberdade tantas vezes referida como formal? Instituições solidárias, fábricas e prisões aparecem tão vinculadas nas falas dos trabalhadores que é impossível não entender ou não ouvir o que eles dizem.

A fábrica, a empresa como um todo, as situações concretas, experimentadas e introjetadas de domínio do capital têm significações múltiplas. Elas variam não só dentro da hierarquia que se monta dentro dos modelos gerenciais, mas segundo o gênero, setor, tempo de permanência, grau de estabilidade, etc. A empresa que se constituiu no objeto desta investigação, considerada parte do projeto de modernização da indústria no Brasil, é caracterizada, como se viu, concomitantemente como mãe, madrasta, esposa, prisão, bomba, lugar de vida e de morte, labirinto. Foi motivo de orgulho profissional, mesmo para os mais fervorosos militantes cutistas que 
RIZEK, Cibele Saliba. Interrogações a um campo teórico em crise. Tempo Social; Rev. Sociol. USP, S. Paulo, 6(1-2): 147-179, 1994 (editado em jun. 1995).

atuavam em seu interior. Também foi vista como fonte de vergonha e insatisfação. O mesmo trabalhador que enaltece as qualidades da "sua" empresa reconhece que "às vezes, a gente tem que dar uma de pelego, porque tudo o que a gente tem, e não é pouco, veio de lá".

Procurando elucidar as referências presentes nas concepções de subjetividade, ainda é preciso mencionar nuances e diferenças. A primeira diz respeito aos processos que colocam a necessidade de pensar as dimensões subjetivas do trabalho e dos trabalhadores para o pensamento anglosaxão e para a discussão brasileira, assentada em outras questões referidas à história recente do movimento e das classes trabalhadoras, tal como vem se desenvolvendo a partir do final dos anos setenta. Se lá, como aqui, as subjetividades dos trabalhadores passam a ser consideradas como elementos explicativos importantes, por outro lado, o que se busca explicar em meados dos anos oitenta está referido, lá, à produção do consentimento no interior dos chãos-de-fábrica, e aqui, à resistência dos trabalhadores, à sua capacidade de se constituírem em interlocutores, em meio a um conjunto de crises econômicas recorrentes, em meio a um processo de "modernização" e racionalização técnica da produção, em meio a uma década que muitos consideraram como "perdida".

Em relação às questões colocadas pelo campo da sociologia do trabalho no Brasil, cabem ainda algumas observações. Parece ser sobretudo nos anos sessenta que tomam forma, com a questão da modernização e das novas formas de industrialização, as dimensões que estão perpassadas pelos problemas do "desenvolvimentismo", das "transformações estruturais" na sociedade brasileira. É assim que começam a se delinear questões relativas a uma pergunta fundamental para uma sociologia do trabalho: quem são, qual o papel que representam, qual o lugar que ocupam os trabalhadores na dinâmica dessa sociedade?

Se a estas perguntas respondemos com estudos ora pontuais, ora excessivamente generalizantes, pode-se, por outro lado mapear perspectivas diversas (que geraram e ainda geram respostas diversas a essas mesmas questões), não só em trabalhos que se filiam a uma abordagem mais propriamente sociológica, mas em produções que se articulam, mais ou menos, com as leituras que os informam, com enfoques que têm origem na antropologia, na economia, na historiografia, nas abordagens que se filiaram a uma psicopatologia (ou psicodinâmica) do trabalho. Pode-se, mesmo que arriscadamente, afirmar que uma questão específica está ainda permeando um diálogo tenso entre modos e pontos de partida contrapostos para a explicação do "social". "Objetivismo" e "subjetivismo", subjetividades pensadas individual ou coletivamente, formas distintas de instituição acadêmica das considerações relativas à classe operária e suas práticas de trabalho podem ser referidas a diferentes questões que a cada momento, especialmente ao longo dos últimos anos, levaram os pesquisadores e estudiosos a encenar de maneiras diversas as formas de constituição e os agentes (ou sujeitos) des- 
ses processos de trabalho.

Deste ponto de vista, os estudos dentro de um campo em que convergem abordagens diversas sobre o trabalho, a classe trabalhadora, seu movimento fabril e sindical tomam impulso visivelmente quando os trabalhadores brasileiros irrompem na cena pública a partir do final dos anos setenta. Toda uma nova leitura das maneiras pelas quais a classe operária era compreendida até então passa por um esforço de reinterpretação que não parece ter se esgotado ${ }^{26}$.

Perpassando o campo das questões que se colocaram nos anos oitenta, uma das descobertas mais significativas nas reinterpretações da história dos trabalhadores brasileiros se dá em contraposição ao economicismo e objetivismo das análises anteriores. No transcorrer da década, novas e instigantes dimensões são colocadas: a questão de uma revolução tecnológica em curso, as novas dimensões da ação política dos trabalhadores (ainda que não necessariamente a partir dos lugares tradicionais), as questões relativas à construção dessa ação no bairro, na moradia, nas igrejas, a questão do cotidiano, a visão das lutas fragmentárias no interior das empresas. As dimensões simbólicas, culturais, subjetivas permitem que se incorpore à historiografia e à sociologia do trabalho, nos últimos dez anos, um conjunto de novos objetos e enfoques que vão desde uma farta quantidade de estudos de caso, de etnologias fabris e estudos sindicais, até trabalhos que buscam perspectivas comparativas. A compreensão dos processos de trabalho e suas heterogeneidades, de um lado, e as preocupações relativas à possibilidade de generalização de alguns achados, de outro, demonstram que a questão da heterogeneidade estava na ordem do dia.

Em meio a estas novas preocupações, em um texto do final da década, Elisabeth Lobo comenta que os significados culturais dos conceitos da sociologia do trabalho foram construídos na multiplicação dos estudos de história social e de cultura, que geraram uma nova linguagem para falar da subjetividade no trabalho Afirma, ainda a inexistência de áreas separadas institucionalmente da vida social nas quais as formas de consciência se constituem, já que, no seu conjunto, "mentalidades e subjetividades se formam e se expressam em cada esfera da existência - inclusive no trabalho e inclusive no trabalho tecnológico" (Lobo, 1991, pg. 201).

Nos anos oitenta, desde o seu início, desenvolveram-se pesquisas sobre processos de trabalho e organização do trabalho fabril. De um lado, os "chãos-da-fábrica" precisava ser, afinal, mais bem conhecidos. De outro, os processos de transformação da base técnica que ocorriam em âmbito internacional desde meados dos anos setenta, chegavam para ficar, no bojo da crise econômica, entre 1981 e 1983. A partir destas duas dimensões que muitas outras questões são problematizadas, ou revisitadas. Alguns dos mais significativos estudos sobre o trabalho e os trabalhadores no Brasil centram sua investigação quer no âmbito de novas tecnologias e da heterogeneidade de processos intrafabris, quer nas dimensões cultu- 
rais, simbólicas, subjetivas de parcelas de trabalhadores, abordando temas como a construção de práticas e sua especificidade, a construção de identidades, etc.

Mais uma vez, entretanto, novos aportes são colocados a partir do que se começou a denominar "reconversão econômica". Trava-se de toda uma discussão interdisciplinar a respeito de formas distintas de exploração da força de trabalho relacionadas a formas gerais de reprodução e acumulação do capital: trata-se fundamentalmente de discutir - freqüentemente sob a inspiração da teoria da regulação, originária da economia - as dimensões sócio-políticas do taylorismo, fordismo, fordismo periférico e pósfordismo ou especialização flexível. No bojo da mais recente globalização, que atingiu dimensões e proporções pouco antecipadas pela reflexão acadêmica, essa discussão vem informar o campo da sociologia do trabalho com estudos híbridos, a partir dos quais se passa a falar de um "modelo" japonês, sueco, ao mesmo tempo que se constatam novas linhas de clivagem, novas formas de fragmentação, por obra da falência dos mecanismos clássicos de universalização pelo mercado ou pelo Estado-previdência incompleto e já esgarçado.

Se por um lado se escapa das "determinações econômicas" rigidamente interpretadas para encontrar questões que vinham de encontro a abordagens oriundas de um esforço de releitura da história (em especial, tributárias de autores como Thompson e Perrot, entre outros) e a contribuições da antropologia, por outro, um raciocínio de origem econômica põe-se como questão que permeia desde a globalização e a mundialização da produção em patamares nunca antes realizados, até o "chão-de-fábrica" com novas tecnologias, controle estatístico de processos, Total Quality Control, e tudo o mais a que nos acostumamos chamar de "novas formas de gestão da força de trabalho".

Na década de oitenta, entretanto, as questões relativas às dimensões do trabalho não escapam da emergência de um conjunto de questionamentos. As categorias e conceitos clássicos vão cedendo lugar a enfoques e filiações teóricas que cada vez mais se sabem interpretação e leitura do "real", em oposição a uma forma unitária de explicação. As dimensões da pluralidade, as encenações de temporalidades que rompem a idéia da "grande narrativa", e tantas outras interrogações são, por assim dizer, uma das faces do que se denominou crise dos paradigmas clássicos. A idéia de crise se estende também às formas clássicas de representação em muitos níveis: sindical, partidário, parlamentar, ainda que tanto nos âmbitos sindical e partidário a realidade brasileira apresentasse importantes especificidades em relação à situação internacional ${ }^{27}$.

Por meio desse conjunto de crises o lugar e o espaço do fazer social e político passam a ser percebidos como dimensões plurais. Recolocam-se também as discussões desse fazer social e político a partir de sujeitos, subjetividades e identidades, ou ainda, posições “de sujeito organizadas no âmbito 
de uma estrutura discursiva instável" (cf. Laclau, 1986).

Vincula-se por essa via a idéia de sujeitos múltiplos às formas de seu discurso, às maneiras como se enunciam e se reconhecem em identidades negociadas, construídas em relação à configuração de outras identidades, em relação, portanto, a alteridades que se reconhecem como tais.

Nos discursos e falas coletados, pôde-se constatar, a partir do caráter pouco codificado e lacunar das matrizes discursivas do trabalho, identidades que se forjam pela "negociação", pelo empréstimo de matrizes arraigadas em esferas da vida e das representações que definem e se apropriam de alteridades, ainda que, de alguma forma, referidas a lacunas, ao que falta, ao que não se concluiu. Essa inconclusão que vincula identidades a pertencimento, identidades a direitos e seu reconhecimento na esfera pública, foi tematizada por alguns autores ${ }^{28}$ que destacam o desenvolvimento do sentimento de pertinência operária mediatizado pelo "direito a ter direitos", em choque com "uma forma de dominação que controlava a produção e a vida social por inteiro", criando formas de microorganização e reivindicação de direitos que atravessam a história operária brasileira (Lopes, 1991, p. 93).

Ao longo dos últimos anos, adquirem importância para o pensamento e para as discussões a respeito da classe operária, as questões relativas a uma luta que veio se inscrevendo com mais força, ainda que de forma menos generalizada do que se pode supor, nas esferas da publicização de seus direitos dentro e fora dos espaços de trabalho. Estabeleceu-se um diálogo que perpassa as conquistas democráticas e a construção dos novos lugares que os trabalhadores vieram ocupando nessa cena. A partir da compreensão que desconstrói as esferas do trabalho como mundos insulares, estes temas indicam a necessidade de inscrever as discussões sobre os trabalhadores, suas representações e suas práticas em uma tessitura de relações que tensionam uma esfera pública construída a partir de uma constante privação de direitos, o que coloca um campo de problematizações que se tecem no terreno de uma "experiência de liminaridade, uma experiência que transcorre nas frágeis fronteiras que separam o 'trabalhador honesto' (...) desse mundo invertido, desenhado em negativo da pobreza..." (Telles, 1992, p. 36-37).

O que se pôde notar nessa incursão na experiência dos trabalhadores inseridos na esfera de um trabalho estável e relativamente bem remunerado, incluídos entre aqueles que detêm tantos atributos e distinções que puderam ser caracterizados como "aristocracia operária", é, no entanto, a outra face deste pauperismo que marca a "normalidade" da vida social brasileira. Suas inseguranças são de outra ordem. Se a precariedade e a instabilidade da pobreza não os atinge de perto, ela está todo o tempo presente como ameaça. Outras formas de desqualificação, diversas daquelas que perpassam a condição da pobreza, desenham sua condição: estão, por outros caminhos, privados da legitimidade e do reconhecimento como sujeitos 
portadores de interesses legítimos e, como tal, sujeitos de direitos, entendidos não na sua expressão jurídica, mas nas suas muitas dimensões simbólicas, capazes de desnudar pela expressão pública um conflito que se manteve enclausurado. Nessa clausura configurada pela privatização do lugar público do trabalho, na solidão de pertinências e identidades que só se constituem pelo reconhecimento de alteridades, uma explosão quebrou seu silêncio. Na defesa da vida, na luta contra uma morte anunciada e denegada, ocuparam o lugar dos que se fazem valer no mundo público da ação e da palavra.

Apesar de toda a riqueza e diversificação do debate e das categorias explicativas que se enunciaram recentemente nos estudos sobre o trabalho, freqüentemente, seus limites tiveram que ser considerados em face dos rumos de pesquisa e investigação. Evidentemente, os aportes teóricos estão, de certa maneira, a demandar constantemente a construção de mediações para que possam dar conta de estudos de situações empíricas. Entretanto, neste caso, o que parece se afigurar é, até mesmo, uma dificuldade de nomeação. Diante das situações concretas e da maneira como foram narradas pelos trabalhadores, as categorias de consentimento e resistência, têm seu poder explicativo bastante comprometido. Se entendidas a partir de uma conceituação estanque, as dimensões públicas e privadas, também se empalidecem. Quando referidas às temporalidades múltiplas, apesar de sua fertilidade, algumas noções, como a de "fronteiras de controle", se complicam. $\mathrm{O}$ mesmo se dá em relação às concepções de qualificação. Os processos de formação e socialização que resultam em competências no interior da fábrica, passam, mas não se restringem aos mecanismos e instâncias formais. Parte significativa dos atributos necessários ao bom desempenho das tarefas, advém da experiência concreta de trabalho. De um lado, estes atributos são fortemente banalizados ou naturalizados tanto pelas gerências quanto pelos trabalhadores, já que, tal e qual as qualificações femininas, estão referidos a um mundo de experiências fabris qualificadas como domésticas e familiares, ainda que seu caráter masculino seja afirmado e reafirmado.

Ainda que esse conjunto e experiências tenham tido lugar na empresa, ainda que as imagens configuradas nas falas digam respeito à experiência fabril, é possível identificar, em relação às formas de controle, à discussão do consentimento e da subjetividade, assim como em relação à dinâmica da qualificação, que a literatura vem apontando a necessidade de ir além das instâncias fabris, além dos limites das empresas, ao mesmo tempo que esses apontamentos apresentam lacunas no que diz respeito às formas de transitividade entre a fábrica e as outras instâncias onde se tecem relações sociais e simbólicas. Nesse caso, se a empresa é um ponto de intersecção entre tantas outras práticas e lugares, essa transitividade nem poderia deixar de ser considerada, já que ela está dada pelos discursos que localizam de fora para dentro da empresa, as referências metafóricas que a 
qualificam. Em uma empresa estatal, a primeira identificação em negativo que pode ser reconhecida é a sua não coincidência com o caráter público, evidenciada por todos os discursos dos trabalhadores. Essas imagens e significações puderam ser reconhecidas pelo poder de falas e discursos que denunciaram uma forte colonização da vida pelas dimensões privadas, entendidas no sentido literal ou mítico.

As metáforas enunciadas por esses trabalhadores apontaram para uma forma inusitada de apropriação e de consciência de suas experiências, para imagens que, em seu caráter múltiplo e flutuante, configuraram essa experiência vista e vivida como dimensão privada. A domesticidade das relações entre trabalhadores e empresa, a privatização de sua inserção, o caráter despótico que produziu e reproduziu seu silêncio nas arenas públicas, não são apenas resultantes de uma forma de gestão, não podem ser vistas como alienação ou ideologia. Eles sabem e denunciam, ainda que de maneiras tortuosas e multifacetadas, a concretude de seus laços, o caráter paradoxal e ambíguo de sua situação, a banalização, o não reconhecimento de sua experiência, instabilizada e desmaterializada pelos novos modos operatórios mediados por computadores. Qualificações que se desvanecem, ao serem reconhecidas como "vícios", sociabilidades que se destroem e se repõem, significações que se desfazem e refazem, recompõem labirintos. Diante destas injunções, dessas práticas e significações, pondo a prova alguns dos conceitos e noções advindos dos aparatos explicativos da sociologia do trabalho, impôs-se a constatação de que sua utilização empobrecia, em vez de explicar, alguns desses achados. Essa situação concreta, que atesta permanências e, concomitantemente, denuncia temporalidades, que demonstra consentimento, mas concomitantemente enuncia conflitos invisibilizados, colocou diante da necessidade de sua interpretação, um conjunto de negatividades: modelos de gestão que, apesar de despóticos, não tratam os trabalhadores como máquinas, cujas mediações são tão sóciopolíticas quanto imaginárias, que apelam para a construção de uma força de trabalho qualificada, mas, ao mesmo tempo, banalizam e impedem o autoreconhecimento dessa qualificação, que apostam em uma resposta aos imprevistos capaz de evitar catástrofes, mas se furtam de investimentos de sua responsabilidade. Ainda que caiba pensar que não basta descrever ou reproduzir as caracterizações encontradas, é preciso considerar que, a partir da concretude do trabalho, a empresa se configura em imagens que a dotam de qualidades diversas: lugar que provê a vida e onde se afirma a possibilidade de ser alguém; lugar em que se encontra a morte e o medo; lugar definido por empréstimo do já experimentado, conhecido, plausível, por apropriações que estabelecem a ponte e a transferência para o permanentemente desconhecido, porque instabilizado terreno do trabalho encapsulado, fora do qual, "não são ninguém". Enquadrar essas imagens nas categorias que univocamente lhes atribuiriam a qualidade de consentimento ou resistência, de escolhas e práticas objetivadas, ou formas de con- 
RIZEK, Cibele Saliba. Interrogações a um campo teórico em crise. Tempo Social; Rev. Sociol. USP, S. Paulo, 6(1-2): 147-179, 1994 (editado em jun. 1995).

trole, ideologia e alienação, equivaleria a ignorá-las.

\section{Recebido para publicação em março/1995}

RIZEK, Cibele Saliba. Questions on a collapsing theoretical field. Tempo Social; Rev. Sociol. USP, S. Paulo, 6(1-2): 147-179, 1994 (editado em jun. 1995).

\begin{abstract}
This article is based on the discussion of some concepts developed by the Labour Process Theory, specially what can be considered as a loss of centrality of labour in contemporary societies, the workers subjectivity and the ideas of control and consent. The questions proposed in this paper are formulated during the research about the workers of the first State petrochemical enterprise in Brazil, and the metaphors they constructed to describe the place they work, their work conditions and themselves. Their practices and images could be considered as a result of sucessful manegement. The refuse of this hypotheses forced another and unusual form of explanation and the review of the main concepts used by the Labour Process Theory.
\end{abstract}

\section{Notas}

${ }^{1}$ Este texto constituiu-se a partir de um conjunto de interrogações colocadas pela análise dos dados coletados na pesquisa realizada para a elaboração de tese de doutoramento (ver Rizek, 1994).

${ }^{2}$ Diante da crise mundial que tem lugar desde os anos setenta, várias respostas foram colocadas. Ao absenteísmo e baixa qualidade do trabalho, contrapõem-se o toyotismo e a automação, a desregulamentação e "modernização", o reavivamento das relações de mercado e de sua capacidade de seleção, vinculados às propostas neoliberais, o que acabou por recolocar essa questão em novos termos. Ver Oliveira (1988).

${ }^{3}$ Essa afirmação, por sua vez, faz recordar uma obra brasileira, marcadamente enraizada no final dos anos oitenta (cf. Sader, 1988).

${ }^{4}$ Sem querer estender demais essa discussão, quem quer que leia os capítulos do primeiro volume de $O$ Capital, relativos ao processo de trabalho na indústria mecanizada, não pode enxergar naquela caracterização um trabalhador que permaneça detendo saberes ou mesmo persista com alguma possibilidade de ser sujeito do processo. Esse papel, Marx deixa claro, muda de mãos. Não é mais o trabalho vivo que submete o trabalho morto, mas o contrário: é o trabalho morto e cristalizado na máquina que detém o controle do trabalho vivo, no momento mesmo em que as ferramentas mudam de mãos. Marx, ao teorizar sobre o trabalho industrial, tinha como horizonte a construção da força de trabalho como mercadoria, empreendida nas suas relações com o capital.

${ }^{5}$ Ver a esse respeito a discussão que faz Arendt (1991).

${ }^{6}$ ver a esse respeito a discussão estabelecida em Ewald (1986).

${ }^{7}$ Deste ponto de vista é importante observar que a PQU, assim como outras empresas do Pólo de Capuava mantém um programa de visitas das famílias dos trabalhadores à empresa nos finais de semana. Na Unipar esse programa tem o sugestivo nome de open house. Nas
UNITERIMS:

labour process, subjectivity and

labour,

management control. 
duas empresas - PQU e Unipar - os objetivos são os mesmos: demonstrar às mulheres e filhos dos trabalhadores as "maravilhas" técnicas, bem como integrá-los ao clima de trabalho "amistoso e cordial" que nelas se desenvolve.

${ }^{8}$ Trata-se especialmente de um momento de ruptura violenta na forma pela qual se estruturavam as relações entre empresa e trabalhadores. Esse momento aconteceu por ocasião de um acidente com vítimas provocado pela explosão de um dos fornos da empresa. O resultado dessa explosão configurou-se em um processo, movido pelo sindicato contra a empresa, no qual revelaram-se os conteúdos e formas da irresponsabilidade patronal pela defesa da vida e da produção. Esse acidente, ocorrido em julho de 1992, rompe formas de consentimento e de representação dos trabalhadores construídas ao longo de 20 anos de funcionamento da empresa.

${ }^{9}$ Alguns exemplos podem e devem ser citados. Desse ponto de vista, vale a pena recuperar o trabalho de Regina Morel que aponta temas bastante conectados com os que foram tratados na busca de caracterização dos trabalhadores petroquímicos: orgulho profissional, valorização do passado, uma forma "paternalista" de gestão, o caráter pioneiro da empresa, a perda deste estatuto, etc. Entretanto, não é por acaso que a valorização do passado, no caso dos petroquímicos da primeira central de matérias-primas do país se dê pela imagem materna da empresa, o que também pode ser verificado em entrevistas reproduzidas no trabalho citado: "Se no primeiro momento, o entrevistado parece reproduzir a idéia da 'Companhia-mãe', num segundo momento opera-se uma inversão: a ênfase com que, posteriormente, procurou valorizar a sua competência e esforço pessoais, opõe-se ao discurso da “dádiva"” (Morel, 1989, p. 448). O mesmo caráter de pioneirismo, a idéia - nesse caso mais claramente colocada - do Estado-patrão, as descrições de uma fábrica militarizada permeiam, com semelhanças bastante evidentes, as análises de José Ricardo Ramalho sobre a Fábrica Nacional de Motores, a FNM. Aqui, o que se ressalta é a mesma imagem da prisão que, ainda que com ênfases diversas, recobre representações das duas situações de trabalho (cf. Ramalho, 1986).

A esse respeito, excelentes contribuições podem ser destacadas, como as de José Sérgio Leite Lopes, em seus dois livros (1978 e 1988).

11 Cabe lembrar aqui o que Helena Hirata chamou, em alguns de seus textos, de condicionantes sociais das transformações da base técnica ou de modelos de gestão. Essa questão é tão mais importante quanto mais se considera o que são os espaços de trabalho no Brasil, quais são as condições reais de sua utilização, como se constituem em lugares em que a cidadania acontece pelo avesso, mesmo nos chamados setores dinâmicos e modernos da economia brasileira.

12 Se o ponto de partida desta discussão é a obra de Braverman, é importante frisar que o que este autor pretendeu, e realizou com bastante sucesso, foi uma atualização dos pressupostos marxistas em face da realidade do capitalismo monopolista, momento em que tenderia a ocorrer uma extensa fragmentação e especialização do trabalho, no interior de um processo de desqualificação. Para este autor, o móvel central da organização e do controle gerencial do processo de trabalho é a separação entre concepção e execução das tarefas da produção. Para os trabalhadores, isso significa alienação, para o capital, um problema relativo à gerência. Braverman assimila ainda taylorismo, controle gerencial e avanço tecnológico, o que lhe permite pensar na introdução de formas mais avançadas de maquinaria como um elemento que tanto compôs como complementou o taylorismo, tendo acrescentado à desqualificação e fragmentação do trabalho a criação de um aparato de concepção. Cabe ainda notar que o autor se filia a uma leitura do marxismo a partir da qual os aspectos "subjetivos" seriam considerados como parte integrante do desenvolvimento da consciência de classe. (cf. Ramalho, 1991, p. 33).

13

Cabe aqui referir ao quanto é discutível a idéia de que não é possível mensurar, para o capital, a extração de mais valia. Afinal, essa afirmação de Burawoy parece enredar da mesma maneira capitalistas, gerências e trabalhadores em um mesmo e idêntico processo de obscurecimento ou fetichização de suas relações.

14 Ver Littler, Edwards, Thompson e outros em Knights (1990).

15 Cabe explicar o que Knights chama de essencialismo. Trata-se especialmente da afirmação clássica de Marx referida ao processo pelo qual há uma essência humana que se 
objetiva e se produz pela transformação deliberada da natureza, processo pelo qual e no qual também e concomitantemente se produzem os próprios homens.

Aqui é importante ressaltar que a leitura que o autor faz de Foucault, apelando a seus trabalhos em uma busca de um sujeito e de uma subjetividade ausentes causa estranheza, no mínimo, e perplexidade, no máximo. Se, de um lado, cabe fazer a crítica ao essencialismo a partir de Foucault, por outro lado é preciso notar, como faz J. C. Bruni, apenas para citar um exemplo, que o sujeito foucaultiano é um sujeito silenciado, calado por saberes e poderes que falam (e são ouvidos) em seu nome (cf. Bruni, 1989).

Para uma crítica às concepções de C. Déjours, ver especialmente Doray (1989). Assim, o autor afirma: "A visão ontológica que emana da obra de C. Déjours remete a essência humana a uma abstração biológica e a história e a socialidade a uma questão de meio ambiente. Ao procurar na biologia segredos que ela é incapaz de desvendar, o autor acaba por empobrecer o próprio sentido das prodigiosas descobertas que passa em revista". ( $\mathrm{p}$. 83)

18 Como se pode constatar no trecho que se segue: "No debate acadêmico recente, o conceito de fordismo é usada tanto em nível de planta industrial (para se referir ao processo de trabalho) quanto em nível de sociedade (para se referir ao que a escola regulacionista chama de um regime de acumulação). Nesse artigo, o fordismo está relacionado ao primeiro nível, ou seja, uma prática de organização de trabalho, encontrada tipicamente na produção em massa semi-automatizada" (cf. Carvalho \& Schmitz, 1990).

A distinção discreto/contínuo, forma e propriedade tem sido elaborada para dar conta de diferenças e heterogeneidades fundamentais para se compreender os processos de trabalho em si. Pode-se mesmo dizer, por exemplo, que o grande impacto da flexibilização e da micro informatização sobre o trabalho industrial ao longo dos anos 80 , se dá nas indústrias de processos de trabalho discreto, como a metal-mecânica, já que elas se caracterizavam mais tipicamente pelo fordismo, além de abrigar, no seu interior, ofícios que enfrentaram um duro e inconcluso processo de diluição ou desaparecimento. As indústrias de processo contínuo, ao contrário, principalmente as indústrias petroquímicas, bastante estudadas pela sua novidade no quadro de sua inserção regional na Bahia e pela intensa mobilização de trabalhadores que lá teve lugar, sofrem o impacto das novas tecnologias de formas bastante diversas, já que se constituíram desde sempre como extremamente poupadoras de mão de obra, além de terem no seu interior poucas carreiras fundamentais, do ponto de vista produtivo, já bastante desligadas de qualquer reminiscência de ofícios. Assim, formas diversas de subsunção do trabalho à gestão do capital, configuram impactos de natureza diversa.

20 Ver a esse respeito Oliveira, O. et alii (1993)

21 Ver especialmente, entre outros, Leite (1990). Embora o objetivo deste texto não se estenda a uma discussão da questão da qualificação, é necessário precisar que o termo polivalência não se confunde com o que se pode reconhecer como "multi-skill". Para uma melhor caracterização desta diferença, ver Salerno (1991).

22 As formas de resistência operária à polivalência aconteceram ou, pelo menos, tornaram-se visíveis em empresas onde a mobilização dos trabalhadores reconhecidamente se constituiu como parte do cotidiano fabril. Nem sempre é possível caracterizar uma percepção imediata da transformação dos conteúdos do trabalho no sentido da transformação do princípio "um homem, um posto, uma tarefa". Entretanto, sob a fórmula "trabalho igual, salário igual" escondeu-se um dos eixos dessa resistência que se vinculava a uma outra maneira de valorização e de autovalorização dos trabalhadores. A transformação de conteúdos e tarefas dos postos de trabalho é um dos elementos de mais difícil negociação com o patronato, mesmo quando há condições de se negociar princípios da organização do trabalho (ver Leite,1990).

23 É interessante notar que a "questão feminina", ou as descobertas que transformam o gênero em uma dimensão presente em todas as esferas da vida, permeiam também os estudos que têm por objeto a linguagem, como se pode perceber pela citação abaixo:

“(...) sem dúvida o maior estímulo ao estudo sócio-histórico da linguagem na passado recente - à análise do poder do discurso, por sua presença ou ausência, para definir, coagir ou permitir; para vitimizar ou transformar em bode expiatório, para exercer hegemonia e 
RIZEK, Cibele Saliba. Interrogações a um campo teórico em crise. Tempo Social; Rev. Sociol. USP, S. Paulo, 6(1-2): 147-179, 1994 (editado em jun. 1995).

organizar o consenso; para fazer, desfazer e refazer mundos vividos - tem sido o feminismo. (...) A erudição feminista (...) expôs os calços ideológicos da usurpação masculina da autoridade lingüística (o direito de falar), além da exclusão tradicional das mulheres do debate. Revelou a operação de padrões duplos que não são menos lingüísticos do que sexuais. Os estudos feministas chamaram a atenção para as intermináveis, sub-reptícias e assustadoramente banais operações de discriminação lingüística no lar, no casamento, nas escolas e empregos e no domínio público" (cf. Porter, 1993).

$24 \quad$ É interessante notar, principalmente, que a chamada "questão feminina" quando tematizada, quer nas dimensões relativas à esfera do trabalho, quer nos estudos sobre os movimentos sociais tenha colocado, em conjunto com todos os outros sujeitos que adquirem visibilidade através de seu aparecimento na cena pública, a necessidade de uma desconstrução e de uma reconstrução de conceitos e de enfoques teóricos. A partir de novos (ou finalmente visíveis) fenômenos que irrompem na cena pública, como ruptura que se dá no tecido histórico, impõe-se à reflexão a necessidade de interrogar as matrizes por meio das quais a sociologia clássica construiu os princípios que desvendavam as relações sociais. $\mathrm{O}$ vínculo entre estas três questões - as ciências sociais, os movimentos sociais e as questões de gênero, é tematizado por meio de uma interrogação a respeito da tensão existente entre a constituição interna, identitária, de sujeitos coletivos e a linguagem sociológica em Paoli (1991, p. 108).

25 Esta sugestão deve ser referida a Castoriadis (1983). Ver também Boutet (1993).

26 Ver especialmente Paoli, Sader \& Telles (1983) e Sader (1983).

27 A esse respeito ver Offe (1989) e Rosanvallon (1988).

28 Esse enfoque tem sido desenvolvido a partir de Lefort e Arendt por vários autores, entre os quais M. C. Paoli e V. S. Telles.

\section{REFERÊNCIAS BIBLIOGRÁFICAS}

ARENDT, H. (1991) A vida do espírito, o pensar, o querer, o julgar. Rio de Janeiro, Relume-Dumará.

Boutet, J. (1993) Activité de langage et activité de travail. Futur antérieur - paradigmes de travail, Paris, L'Harmattan, no 16, 1993/2.

Braverman, H. (1974) Trabalho e capital monopolista. Rio de Janeiro, Zahar.

Bruni, J. C. (1989) Foucault: o silêncio dos sujeitos. Tempo Social, São Paulo, USP, vol. $1 \mathrm{n}^{\mathrm{o}}$ 1: 199-207. $1^{\circ}$.

Burawoy, M. (1982) Manufacturing consent. Changes in the labour process under monopoly capitalism. Chicago and London, The University of Chicago Press.

Carvalho, R. Q. \& Schmitz, H. (1990) O fordismo está vivo no Brasil. Novos Estudos Cebrap, no 29, julho.

Castoriadis, Cornelius. (1983) A instituição imaginária da sociedade. Rio de Janeiro, Paz e Terra.

Castro, N. \& Guimarães, A. S. A. (1991) Além de Braverman, depois de Buraway. Vertentes analíticas na sociologia do trabalho. In: . Modelos de organização industrial, política industrial e trabalho. São Paulo, ABET. Abril

Dadoy, M. La Polyvalense. (s/d) Collection des études $n^{\circ}$ 54. Paris, mimeo. 
DORAY, Bernard. (1989) Da produção à subjetividade - referências para uma dialética das formas. In: SILVEIRA, Paulo \& DorAY, Bernardo (orgs.). Elementos para uma teoria marxista da subjetividade. São Paulo, Edições Vértice.

Ewald, François. (1986) L'Etat providence. Paris, Bernard Grasset.

Freyssenet, Michel. (1989) A divisão capitalista do trabalho. Tempo Social, São Paulo, vol. I, no 2: 74-82. $2^{\circ}$ semestre.

Habermas, J. (1987) A nova intransparência. Novos estudos CEBRAP, no 18. setembro.

Kergoat, Daniele. (1989) A divisão do trabalho entre os sexos. Tempo Social, São Paulo, vol. I, nº 2: 88-96, $2^{\circ}$ semestre.

Knights, D. \& Willmot, H. (orgs.) (1990) Labour process theory. London, McMillan.

KNIGHTS, D. (1990) Subjectivity, power and the labour process. In: KNIGHTS, D. \& Willmot, H. (orgs.) Labour process theory. London, McMillan.

LAClAU, E. (1986) Os novos movimentos sociais e a pluralidade do social. Revista Brasileira de Ciências Sociais, n 2, vol 1. outubro.

LeITE, M. P. (1990) A vivência operária da automação microeletrônica. São Paulo, 331 p. Tese de doutoramento. FFLCH-USP.

LitTLER, C. (1990) The labour process debate: a theoretical review. In: Knights, D. \& Willmot, H. (orgs.) Labour process theory. London, McMillan.

Loвo, Elisabeth Souza. (1991) A classe operária tem dois sexos. São Paulo, Brasiliense.

Locke, J. (1983) Second treatise of civil government. Apud ARENDT, H. A condição humana. Rio de Janeiro, Forense Universitária.

LoPEs, José Sérgio Leite. (1988) A tecelagem dos conflitos de classe na “cidade das chaminés”. Brasília, Editora da Universidade de Brasília.

. (1978) O Vapor do Diabo. O trabalho dos operários do açúcar. Rio de Janeiro, Paz e Terra.

. (1991) Lectures savantes d'un syndicalisme paradoxal. Dossier, Genèses 3. Mars 1991

Morel, Regina. (1989) A ferro e a fogo. Construção e crise da "família siderúrgica”: o caso de volta redonda. São Paulo, 506 p. Tese de doutoramento. Departamento de Sociologia, FFLCH, Universidade de São Paulo.

Offe, Clauss. (1989) Capitalismo desorganizado. Transformações 
contemporâneas do trabalho e da política. São Paulo, Brasiliense.

. (1984) Trabalho e sociedade. problemas estruturais e perspectivas para o futuro da sociedade do trabalho. Rio de Janeiro, Edições Tempo Brasileiro.

Oliveira, F. (1988) O surgimento do anti-valor. Novos Estudos Cebrap, São Paulo, n 22 , outubro.

. (1992) Prefácio do livro de LipIETz, A. Audácia, uma alternativa para o século XXI. São Paulo, Nobel.

OliveIRA, O. et alii. (1993) Quanto melhor, melhor. Novos Estudos Cebrap. $\mathrm{n}^{\text {o } 36 . ~ j u l . ~} 1993$.

Paoli, M. C. (1991) As ciências sociais, os movimentos sociais e a questão de gênero. Novos Estudos Cebrap, São Paulo, no 31, outubro.

Paoli, M. C., SAder, E. \& Telles, V. S. (1983) Pensando a classe operária: os trabalhadores sujeitos ao imaginário acadêmico. Revista Brasileira de História, São Paulo, Marco Zero, nº 6.

Porter, R. (1993) Introdução. In: Burke, P. \& Porter, R. Linguagem, indivíduo e sociedade. São Paulo, Editora da Unesp.

Ramalho, José Ricardo. (1986) Estado patrão e luta operária. Conflitos de classe na fábrica nacional de motores. São Paulo, 405 p. Tese de doutoramento. Departamento de Ciências Sociais, FFLCH, Universidade de São Paulo.

. (1991) Controle, conflito e consentimento na teoria do processo de trabalho: um balanço do debate. Boletim informativo e bibliográfico de ciências sociais. Rio de Janeiro, Anpocs/RelumeDumará.

Rizen, Cibele Saliba. (1994) O trabalho e suas metáforas: as representações simbólicas dos trabalhadores petroquímicos paulistas. São Paulo, 1994. Tese de doutoramento. Departamento de Sociologia, FFLCH-USP.

Rolle, Pierre (1989) O que é qualificação do trabalho?. Tempo Social vol. II, $n^{\circ} 1: 83-87.2^{\circ}$ semestre.

Rosanvallon, P. (1988) La question syndicale. Hachette, Calmann-Lévy.

SADER, E. (1988) Quando novos personagens entram em cena. Rio de Janeiro, Paz e Terra.

Salerno, M. (1991) Flexibilidade, organização e trabalho operário: elementos para a análise da produção na indústria. São Paulo, 232 p. Tese de doutoramento. Escola Politécnica da Universidade de São Paulo.

Telles, V. S. (1992) A cidadania inexistente: incivilidade e pobreza. 
RIZEK, Cibele Saliba. Interrogações a um campo teórico em crise. Tempo Social; Rev. Sociol. USP, S. Paulo, 6(1-2): 147-179, 1994 (editado em jun. 1995).

São Paulo, 332 p. Tese de doutoramento. FFLCH, Universidade de São Paulo.

Thompson, P. (1990) Crawling from the wreckage: the labour process and the politics of production. In: KNIGHTS, D. \& WiLlmot, H. (orgs.) (1990) Labour process theory. London, McMillan.

ZARIFIAN, P. (s/d) Organisation qualifiante et capacité de prise de décision dans l'industrie. Mimeo

. (1993) Travail industriel, socialisations et liberté. In: Futur antérieur. Paradigmes du travail. Paris, L'Harmattan. 1993/2 